
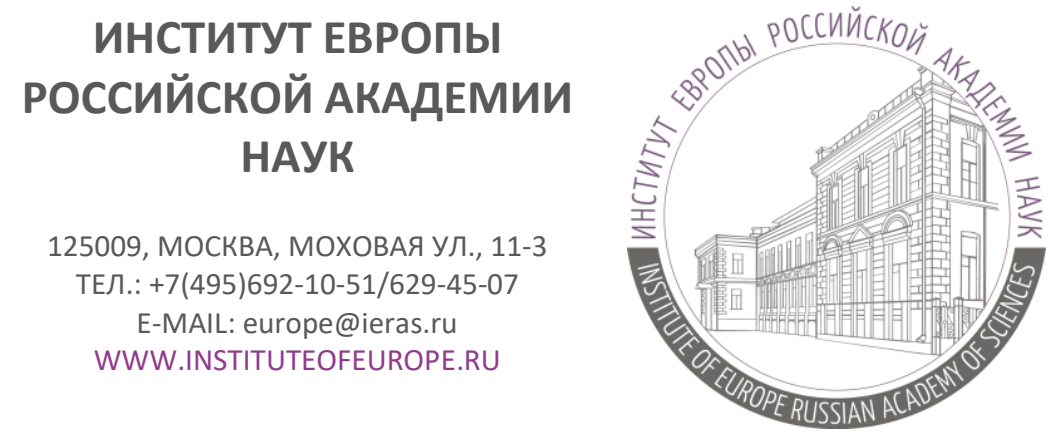

125009, MOSCOW, MOKHOVAYA STR., 11-3

TEL.: +7(495)692-10-51/629-45-07

E-MAIL: europe-ins@mail.ru WWW.INSTITUTEOFEUROPE.RU

\author{
Аналитическая записка №11, 2020 (№194) ${ }^{1}$
}

\title{
Вишеградские страны: ответственность государства в борьбе с пандемией
}

\section{Любовь Николаевна Шищелина}

доктор исторических наук, главный научный сотрудник, заведующая Отделом исследований Центральной и Восточной Европы Института Европы РАН

\begin{abstract}
Аннотация. В статье проанализированы особенности подхода стран Вишеградской группьк к борьбе с глобальной пандемией COVID-19. Особое внимание уделено отличной от общеевропейской мобилизаиионной стратегии, которая свидетельствует о большой ответственности сравнительно молодых членов Европейского союза за свое население. Тем не менее, на фоне охваченных пандемией и погруженных в борьбу с ней по одиночке Германии, Франции, Италии, Испании и других «ядрообразующих» стран ЕС, решительный подход правительств в Будапеште, Варшаве, Праге и Братиславе стал в ряде случаев основой для критики со стороны как Брюссельского истэблишмента в целом, так и ответственных лии ряда стран. Возможно, столь решительному стремлению изолировать себя от «невидимой миграчии» инфекиии способствует накопленный Вимеградскими странами опыт борьбы с неконтролируемой миграчией.
\end{abstract}

Ключевые слова: Вишеградская четверка, Центральная Европа, пандемия COVID-19, антикризисные меры.

В самый критический момент XXI века, связанный с глобальной пандемией COVID-19, руководство Вишеградских стран вновь, как и в разгар миграционного кризиса,

\footnotetext{
${ }^{1}$ DOI: http://doi.org/10.15211/analytics112020
} 
демонстрирует свою способность адекватно воспринимать угрозы национальной безопасности и принимать соответствующие эффективные решения. Происходит это на привычном для правительств в Будапеште, Братиславе, Варшаве и Праге фоне противодействия брюссельских чиновников, ставящих «трансатлантические ценности» выше конкретных человеческих жизней в момент, когда число пострадавших от все еще непонятной для ученых болезни превысило миллион человек, а число умерших десятки тысяч.

Именно правительства стран Центральной Европы, несмотря на то что их население пострадало от вируса меньше, первыми взяли дело спасения от дальнейшего распространения пандемии в свои руки и предложили согражданам конкретные меры. Первым в Европе о необходимости закрытия государственных границ еще в начале марта заявил министр здравоохранения Чехии Адам Войтех, за что сразу же подвергся критике со стороны Председателя Еврокомиссии Урсулы фон дер Ляйен (кстати, врача по образованию), обвинившей Чехию в посягательстве на шенгенские достижения.

\section{Картина эпидемии в странах региона}

В странах Вишеградской группы защитные меры начали принимать гораздо раньше, чем по Евросоюзу в целом, несмотря на небольшое по сравнению с западноевропейскими странами число заболевших и умерших на тот момент. Разница с ведущими странами ЕС колеблется от десятков до сотен раз. К апрелю в Чехии ${ }^{2}$ (при населении 10,6 млн человек) выявлено 4472 заболевших, 59 - скончавшихся, 78 выздоровевших. В Польше (37,9 млн жителей) заболевших меньше (3627), в процентном отношении это лучший показатель, но смертельных случаев больше (79). Выздоровели 116 человек. В Венгрии (9,8 млн жителей) 678 заболевших, из которых 32 не удалось спасти, а 58 вылечили. В Словакии (5,5 млн жителей), которая недавно показала всему миру своих высших чиновников в перчатках и масках на торжественной церемонии вступления в должность нового кабинета министров, ситуация наиболее спокойная - 471 человек заболели, 1 пациент умер, 10 уже поправились.

Если посмотреть на распространение вируса на картах этих стран, то бросается в глаза, что больше поражены столичные регионы и пограничные территории. Так, в Венгрии, кроме Пештского региона, это территории близкие к Австрии, Украине и на границе с Сербией, где всегда наблюдалось большое скопление беженцев. Кроме того, в г. Печ находится известный медицинский университет, где проходят обучение студенты из Ирана - одной из наиболее пострадавших от пандемии стран. В Польше по числу заболеваний лидирует столичный регион с воеводствами к югу. На втором месте Силезия, а в сторону границы с Белоруссией все спокойно. В Чехии в лидерах Пражский регион, а также Оломоуцский, много заболевших в Карловарском крае к границе с Германией. Первым заболевшим и вылеченным в Оломоуце оказался японец. В Словакии лидирует граничащий с Австрией Братисавский край и пограничные

\footnotetext{
${ }^{2}$ Данные на 5 апреля 2020 года. https://coronavirus.jhu.edu/map.html (дата обращения: 1.04.2020).
} 
регионы Тренчин и Жилина, ближайшие к польскому и чешскому регионам с наиболее высокими показателями заболеваемости.

\section{Меры правительств}

В Чехии первые случаи заболевания зафиксированы 1 марта 2020 года. Двое заболевших обнаружены в Праге и один в Усти-над-Лабем на границе с Германией. Как выяснилось, заболевшие накануне вернулись из Северной Италии. В целях предотвращения распространения инфекции 9 февраля остановлено авиасообщение с Китаем, с 10 марта на всей территории страны запрещены собрания, 12 марта введен режим чрезвычайного положения, 16 марта закрыты государственные границы.

В Польше первый пациент госпитализирован 4 марта. Это гражданин страны, вернувшийся незадолго до того из Германии. Сообщение с Китаем закрыто еще 29 февраля, 10 марта создан штаб по борьбе с распространением инфекции, 15 марта введен запрет на въезд в страну иностранцев.

В Венгрии первые пациенты с коронавирусом госпитализированы 4 марта. Это были иранские студентки, обучавшиеся в медицинском университете г. Печ. Связанные с карантином ограничения вводились постепенно с 13 марта, когда был введен режим самоизоляции. Въезд для иностранцев закрыт 17 марта. Штаб по борьбе с пандемией создан еще 31 января, а 30 марта меры по защите от коронавируса обрели статус Закона.

В Словакии первый случай заболевания зарегистрирован 6 марта. Это был словак, заразившийся от вернувшегося из Италии сына, который заболел позже. 9 марта прекращено авиасообщение с Италией, запрещены собрания граждан, 12 марта закрыты границы, а 15 марта введено чрезвычайное положение. Следует отметить, что 29 февраля в стране прошли парламентские выборы, препятствием для которых пандемия не стала. Напротив, здесь до сих пор меньше всего заболевших.

Таким образом, все случаи заболеваний в Вишеградских странах завозные и связаны со странами, где в то время наблюдался рост эпидемии, а границы еще не были закрыты. Тем не менее, опыт Словакии, правительство и президента которых можно считать наиболее эффективными популяризаторами мер личной гигиены, заставляет задуматься о реально действующих мерах борьбы с заражением.

В целом, более низкий уровень заболеваемости в Центральной Европе по сравнению с общеевропейским наводит на мысль не только об адекватности мер правительств, но и о состоянии систем здравоохранения. Возможны два объяснения: либо в этих странах действительно выше уровень принимаемых мер и мобилизационная способность; либо, наоборот, правительства позже приступили к выявлению заболевших, которые синхронно появились в первые дни марта. В последнее верится с трудом, так как год назад на регион обрушилась эпидемия кори, с которой страны «четверки» быстро справились своими силами. Поводом для размышлений может быть и то, что ранее правительства этих стран вопреки нападкам Брюсселя ограничили прием мигрантов и 
их пропуск через свою территорию. Таким образом, напрашивается вывод о более высокой готовности государств Центральной Европы к угрозам извне и адекватному противодействию им.

Пакеты мер, принятые правительствами стран Вишеградской группы, в целом схожи. Разрабатывались они с первых дней февраля (первое заседание штаба по борьбе с коронавирусом в Будапеште состоялось 31 января, а в Чехии мероприятия по выявлению заболевших начались 28 января). В состав штабов входят высшие государственные чиновники, возглавляющие профильные направления; директора клиник и ведущих НИИ, специализирующихся на проблемах здравоохранения, эпидемиологии и т.д.

Среди упомянутых мер³ : прекращение выдачи виз гражданам Ирана, Китая, Южной Кореи (в Чехии с 30 января), отмена авиасообщения с этими странами (с 1 марта), а также с Италией, Испанией, Германией. Введение специальных контрольных мер на границах в отношении граждан стран с высоким уровнем заболеваемости. В марте правительства начинают выделять средства на борьбу с коронавирусом, постепенно введены режимы чрезвычайного положения (11-17 марта), школы и университеты переведены на дистанционное обучение. Одновременно закрыт выезд за границу и въезд в страну, с середины марта объявлен всеобщий карантин (запрещены массовые мероприятия, собрания по поводу государственных праздников). Приняты меры по поддержке медицинских работников, многодетных семей, среднего класса. Введены послабления по кредитам и ипотеке, и другие меры по поддержанию работоспособности экономики, в том числе с привлечением армии как наиболее дисциплинированной и направляемой части общества.

В 20-х числах марта карантинные меры ужесточены, введен запрет для граждан, не занятых в жизнеобеспечивающих отраслях, покидать место проживания. Исключением является осуществление необходимых покупок в близлежащих магазинах и аптеках. Появилось новое расписание работы магазинов и регламент их посещения (время, количество одновременно находящихся людей, дистанция между ними). И в Польше, и в Венгрии с самых первых дней национальной кампании по борьбе с коронавирусом были привлечены войска. Военные участвуют в обеспечении функционирования наиболее важных предприятий и в помощи госпиталям, патрулировании и т.п.

\section{Совместные меры}

13 марта в рамках председательства Чехии в B4 министры иностранных дел Вишеградской группы проводят онлайн-консультацию с приглашением министра иностранных дел Германии. Среди вопросов - меры по борьбе с распространением пандемии в Центральной Европе. В ходе встречи министр иностранных дел Чехии

\footnotetext{
${ }^{3}$ Данные собраны по официальным сайтам правительств Вишеградских стран: https://koronavirus.gov.hu/intezkedesek ; https://onemocneni-aktualne.mzcr.cz/covid-19 ; https://www.minv.sk/?tlacove-spravy\&sprava=koronavirus; https://www.gov.pl/web/koronawirus (дата обращения: 1.04.2020).
} 
Томаш Петршичек сказал, что «борьба с распространением COVID-19 не может вестись только на уровне отдельных государств. Для преодоления глобальной угрозы должны быть мобилизованы общие ресурсы». ${ }^{4}$ Одобрено решение правительства Германии сделать исключение для стран «четверки» в отношении запрета экспорта товаров медицинского назначения.

Что касается ЕС, которым ныне руководит профессиональный врач, побывавшая министром обороны, создается впечатление явной пробуксовки действий отметившей в марте 100 дней со вступления в должность команды Урсулы фон дер Ляйен. Если посмотреть на тематику заседаний, то лишь 10 марта в повестке Еврокомиссии появляется тема спасения экономики, куда также входит и вопрос финансирования неотложных мероприятий по борьбе с заболеванием (поддержка исследований, обеспечение граждан и медучреждений санитарно-гигиеническими средствами и т.д.). ${ }^{5}$

Реагируя на решение Чехии о закрытии границ, председатель Еврокомиссиии заявила 13 марта: «Моя позиция предельно ясна: Единый рынок должен функционировать. Ничего хорошего нет в том, что страны предпринимают односторонние действия, поскольку эффект домино неизбежен... Некоторые меры контроля могут быть оправданы, однако по мнению ВОЗ ограничения в передвижении людей не самая эффективная мера. К тому же она влечет сильные социальные и экономические последствия» ${ }^{6}$.

Наконец, 2 апреля Еврокомиссия утвердила долгожданный всеобъемлющий «Инструмент солидарности SURE», содержащий широкий спектр мер противодействия коронавирусу. На это выделено 100 млрд евро. ${ }^{7}$ В тот же день председатель Еврокомиссии Урсула фон дер Ляйен сообщила, что встревожена мерами, принимаемыми на волне пандемии в некоторых странах ${ }^{8}$. В первую очередь, она имеет в виду принятый 30 марта Государственным собранием Венгрии Закон о мерах защиты на время эпидемии, который по содержанию можно приравнять к введению чрезвычайного положения (закон предоставляет особое полномочия правительству).

\section{Выводы}

В условиях реальной угрозы жизням граждан Европейского союза каждой стране в срочном порядке пришлось принимать неотложные меры противодействия на

\footnotetext{
${ }^{4}$ Teleconference of Foreign Ministers of the V4 Countries and Germany. March 13th, 2020. URL: http://www.visegradgroup.eu/teleconference-of (дата обращения: 3.04.2020).

${ }^{5}$ Coronavirus crisis: "Commission will use all the tools at its disposal to make sure the European economy weathers the storm". Press release, March 10, 2020. URL:

https://ec.europa.eu/commission/presscorner/detail/en/IP_20_440 (дата обращения: 3.04.2020).

${ }^{6}$ Remarks by President von der Leyen at the joint press conference with Executive Vice-Presidents Vestager and Dombrovskis to present the economic response to the Coronavirus crisis. Statement. March 13, 2020. URL: https://ec.europa.eu/commission/presscorner/detail/en/STATEMENT_20_465 (дата обращения: 3.04.2020). ${ }^{7}$ https://ec.europa.eu/commission/presscorner/detail/en/ip_20_582 (дата обращения: 3.04.2020).

8 Von der Leyen: Kifejezetten aggódom a magyarországi helyzet miatt. Index.02.04.2020. URL: https://index.hu/kulfold/eurologus/2020/04/02/von_der_leyen_aggodik_magyarorszag_koronavirus_torveny/ (дата обращения: 3.04.2020).
} 
национальном уровне. Правительства стран Центральной Европы быстрее остальных в ЕС оценили масштаб угрозы и приняли адекватные меры, направленные на сохранение жизней своих граждан.

Тем не менее, в Брюсселе гораздо быстрее реагировали не на насущные потребности государств-членов, а на чрезвычайные меры их правительств, критикуя их и угрожая санкциями. Можно сказать, что опыт борьбы с распространением пандемии во второй раз после миграционного кризиса продемонстрировал слабость «ценностного багажа» Евросоюза, общеевропейской солидарности на фоне синхронности действий правительств «четверки» в свете реальных угроз здоровью населения. В целом, сложившаяся ситуация по мере ее преодоления будет требовать новых подходов к смыслу ЕС и его системе ценностей, а также повлечет за собой перераспределение ролей.

В условиях, когда Россия считает возможным оказывать помощь другим странам Европы и США, предложение помощи странам Центральной Европы было бы оценено там по достоинству. Тем более, что в этом регионе Россия осуществляет достаточно активное экономическое сотрудничество.

Annotation. The article analyzes the approach of Visegrad countries to fighting COVID-19 pandemic. It is clearly different from the pan-European mobilization strategy, demonstrating greater responsibility of the relatively young EU members for their population. Compared to Germany, France, Italy, Spain and other "core» EU countries, caught up in fighting the pandemic by themselves, the resolute approach of Budapest, Warsaw, Prague and Bratislava provokes criticism from both the Brussels establishment and officials of some countries. Perhaps, the recent experience of Visegrad countries' active fighting against uncontrolled migration explains their determination to halt the «invisible migration» of coronavirus.

Keywords: Visegrad four, Central Europe, COVID-19 pandemic, anti-crisis measures.

Дата выпуска: 5 апреля 2020 года.

Материал доступен для скачивания по адресу: www.instituteofeurope.ru/publications/analytics 